\title{
Detection of Pathogens Associated with Psyllids and Leafhoppers in Capsicum annuum L. in the Mexican States of Durango, Zacatecas, and Michoacán
}

\author{
K. D. Swisher, ${ }^{\dagger}$ United States Department of Agriculture-Agricultural Research Service (USDA-ARS), Temperate Tree Fruit and Vegetable
} Research Unit, Prosser, WA 99350; J. E. Munyaneza, USDA-ARS, Temperate Tree Fruit and Vegetable Research Unit, Wapato, WA 98951; and R. Velásquez-Valle and J. Mena-Covarrubias, Campo Experimental Zacatecas, INIFAP, Calera de V.R., Zacatecas, C.P. 98500, Mexico

\begin{abstract}
In fall 2014, 5 to $75 \%$ percent of chili and bell pepper (Capsicum annuum L.) in commercial fields located in the Mexican states of Durango, Zacatecas, and Michoacán had symptoms of deformed, small, mosaic, curled, and chlorotic leaves; shortened internodes; plant dwarfing; or phyllody and rosetting leaf tips. At the same time, leafhoppers and psyllids were observed in the fields, and more than 50 beet leafhoppers (Circulifer tenellus) and nearly 300 potato psyllids (Bactericera cockerelli) were collected from the pepper plants and adjacent weeds. Based on the insect pressure and observed symptoms, nearly 400 pepper samples were collected across this region of Mexico and tested for the presence of leafhopper- and psyllidassociated pathogens. In all, $76 \%$ of the pepper samples were found to be infected with 'Candidatus Liberibacter solanacearum', beet leafhopper-

transmitted virescence agent (BLTVA) phytoplasma, a strain of a curtovirus, or a combination of any two or three of these pathogens. Additionally, $77 \%$ of the collected leafhoppers and $40 \%$ of the psyllids were infected with one or more of these pathogens, in addition to Spiroplasma citri. Specifically, the leafhoppers were infected with BLTVA phytoplasma, S. citri, or a strain of curtovirus. Of particular interest, potato psyllids were not only infected with ' $\mathrm{Ca}$. L. solanacearum' but also with phytoplasmas that belong to the groups $16 \mathrm{SrVI}$ subgroup A and $16 \mathrm{SrI}$ subgroup A. The presence of mixed infections in pepper plants and the insect vectors highlights the need for growers to effectively control both leafhoppers and potato psyllids from solanaceous crops in this region of Mexico in order to prevent the spread of these bacterial and viral pathogens.
\end{abstract}

Dry chili pepper (Capsicum annuum L.) is among the economically important crops currently produced in central Mexico. Numerous plant pathogens have been identified in pepper in the central region of Mexico in the past decade, including 'Candidatus Liberibacter solanacearum', phytoplasmas, curtoviruses, Tobacco mosaic virus, Cucumber mosaic virus, Potato virus $Y$, Pepper mottle virus, and Tobacco etch virus, creating a serious cause for concern among growers (Camacho-Tapia et al. 2011; Mauricio-Castillo et al. 2015; Robles-Hernandez et al. 2011, Velásquez-Valle et al. 2008, 2012). Many of these bacterial and viral pathogens are transmitted among pepper and other crop or weed hosts by insect vectors.

The bacterial pathogen ' $\mathrm{Ca}$. L. solanacearum' is vectored by the potato psyllid Bactericera cockerelli (Šlc), and first was identified in the central Mexico state of Michoacán in 2008 (Camacho-Tapia et al. 2011). Infection rates were observed at 4 and 23\% in 2012 and 2013, respectively (Rojas-Martínez et al. 2016). This bacterium also was detected in 2014 in commercial fields in the Mexican state of Durango (VelásquezValle et al. 2014). 'Ca. L. solanacearum' is known to infect numerous solanaceous crops and is responsible for significant economic losses, primarily to the potato industry across the United States, Mexico, Central America, and New Zealand (Greenway 2014; Munyaneza 2012).

Other pathogens of pepper include DNA viruses of the Geminiviridae family, specifically those from the Begomovirus and Curtovirus genera that are vectored by whiteflies and leafhoppers, respectively. Analysis of commercial chili pepper collected in 2010 in the state of San Luis Potosí, Mexico, identified a simultaneous infection of the curtovirus, Beet curly top virus (BCTV-Wor), and the begomoviruses Pepper huasteco yellow vein virus and Pepper golden mosaic virus, in $80 \%$ of the samples tested (Reveles-Torres et al. 2012). Similar to this, simultaneous infection of plant RNA viruses, including Potato virus Y, Cucumber mosaic virus, Tobacco etch virus, and Pepper mottle virus, all of which are vectored by many species of aphids, have been reported in pepper in the central

${ }^{\dagger}$ Corresponding author: K. D. Swisher; E-mail: kylie.swisher@ars.usda.gov Accepted for publication 5 August 2017.

This article is in the public domain and not copyrightable. It may be freely reprinted with customary crediting of the source. The American Phytopathological Society, 2018.
Mexican states of Aguascalientes, San Luis Potosí, and Zacatecas (Velásquez-Valle et al. 2012). During the 2010 season, single pathogen infections were less common than mixed infections, the latter of which ranged from 5 to $66 \%$ of the chili plants collected across all sampling dates (Velásquez-Valle et al. 2012).

Between early and late fall 2014, the beet leafhopper Circulifer tenellus (Baker) and the potato psyllid B. cockerelli were seen in high numbers in and around Capsicum annuum fields of the chili and bell pepper varieties in the states of Durango, Zacatecas, and Michoacán, in central Mexico (J. Mena-Covarrubias and R. Velásquez-Valle, personal observation). Pepper plants in these fields with high insect pressure displayed disease-like symptoms ranging from leaves that were deformed, small, curled, chlorotic, or with mosaic, to shortened internodes and plant dwarfing, phyllody, and rosetting leaf tips. Symptomatic plants ranged between 5 to $75 \%$ across the different commercial fields, presenting a concern for local growers.

The presence of leafhoppers and psyllids, both phloem-feeding insects, suggested that the disease symptoms could be arising from one of several leafhopper- or psyllid-transmitted pathogens. Among the pathogens transmitted by leafhoppers are phytoplasmas, spiroplasmas, and curtoviruses. The beet leafhopper $C$. tenellus is particularly known to transmit the beet leafhopper virescence agent (BLTVA) phytoplasma of the 16SrVI-A group to solanaceous crops in the United States and Mexico (Munyaneza et al. 2006). 'Ca. L. solanacearum' has been linked to potato psyllid transmission in numerous solanaceous crops in the United States, Mexico, Central America, and New Zealand (Munyaneza 2012). It also has been suggested that the potato psyllid can transmit phytoplasmas to solanaceous plants (Garcia-Negroe et al. 2008), though this has not been definitively shown.

To identify the presence of leafhopper- and psyllid-transmitted pathogens, nearly 400 symptomatic pepper plants collected from fields in Durango, Zacatecas, and Michoacán, Mexico, were tested by polymerase chain reaction (PCR) for the presence of leafhopper- and psyllidtransmitted pathogens, including phytoplasmas, curtoviruses, and ' $\mathrm{Ca}$. L. solanacearum'. Simultaneously, more than 50 beet leafhoppers and nearly 300 potato psyllids were tested for the presence of these pathogens, as well as Spiroplasma citri, in the beet leafhoppers. Previous PCR tests of the beet leafhoppers studied herein independently identified dual infection by $S$. citri and BLTVA phytoplasma in the leafhoppers (Swisher et al. 2016, 2017), suggesting that mixed infections may be common in the field. These earlier analyses prompted the current 
study to identify host-pathogen interactions that could play a critical role affecting the overall disease pressure within a field. This study not only identified a range of phloem-limited pathogens throughout pepper fields in Central Mexico but also found high levels of mixed infection of these leafhopper- and psyllid-transmitted pathogens in individual pepper plants.

\section{Materials and Methods}

Source of plant and insect samples. Symptomatic Capsicum annuum (chili and bell pepper) plants were observed in commercial pepper fields (6 to 10 ha in size) in the states of Durango, Zacatecas, and Michoacán in Central Mexico in late September, October, and early November 2014. Locations included Poanas, Durango; Sombrerete, Calera de V.R., Villa de Cos, Laguna Seca, La Blanca, Chupaderos, and Jalpa, Zacatecas; and Yurécuaro, Michoacán. Infection rates were 5 to $75 \%$, depending upon the field. Specifically, symptomatic leaf tissue was collected between late September and October 2014 near Poanas, Durango; Sombrerete, Zacatecas; Calera de V.R., Zacatecas; Villa de Cos, Zacatecas; Laguna Seca, Zacatecas; and La Blanca, Zacatecas from chili pepper plants (C. апnиum) showing symptoms typical for infection by ' $\mathrm{Ca}$. L. solanacearum' (purpling, curling leaves) or big bud phytoplasma, leaf yellowing, leaf chlorosis, small, deformed, or curled leaves, overall plant dwarfing, phyllody, and rosetting leaf tips. In October 2014, leaf tissue from bell and chili pepper plants was collected near Chupaderos, Zacatecas from plants displaying chlorotic or mosaic leaves, or big bud phytoplasma symptoms. In late October and early November 2013, leaf tissue from bell pepper near Yurécuaro, Michoacán and chili pepper near Jalpa, Zacatecas were collected from plants showing mosaic, deformed, curling, chlorotic, or small leaves; or BCTV symptoms of upcurling leaves, shortened internodes, and pale color. All foliar tissue from symptomatic plants was collected, stored in individual paper bags, and shipped to the United States Department of Agriculture-Agricultural Research Service (USDA-ARS) laboratory in Wapato, WA for analysis with the proper permits in place. Foliar tissue was stored at $-20^{\circ} \mathrm{C}$ prior to processing to prevent degradation of the samples.

Leafhoppers and psyllids at or nearby these affected commercial pepper fields in Durango, Zacatecas, and Michoacán, Mexico were sampled using sweep nets. The insects at each site were sorted, and Circulifer tenellus (beet leafhopper) and B. cockerelli (potato psyllid) were collected. For $C$. tenellus samples, females were easily recognized by the dark-margined notch at the base of the ovipositor, and males were identified by their underside, where they have truncated genital plates (the terminal flaps that protect the genitalia look as if they have been cut off transversely), and by the shape of their aedeagus (in ventral aspect) (Nielson 1968). B. cockerelli samples were identified using their characteristic white markings; in particular, the broad, transverse white band on the first abdominal segment, the inverted ' $V$ '-shaped white mark on the last abdominal segment, and the white line (halo) around the circumference of the head (Wallis 1955). Dead leafhopper and psyllid samples were stored in vials and shipped to the USDAARS laboratory in Wapato for analysis. Insect samples for archiving have been stored in $70 \%$ ethanol at the USDA-ARS laboratory in Wapato, WA.

Nucleic acid extractions from plants and insects. Nucleic acids from 156 of the 387 pepper plants were previously extracted (Swisher et al. 2017) and tested by additional methods in this study. The remaining pepper plants were extracted from leaf and stem tissue using the same modified Dellaporta protocol (Munyaneza et al. 2010). All nucleic acids were resuspended in $100 \mu \mathrm{l}$ of water for subsequent molecular analyses. Nucleic acids from $B$. cockerelli were extracted using the cetyltrimethyl ammonium bromide extraction protocol outlined for insect samples (Crosslin et al. 2006). Nucleic acids from all 52 C. tenellus samples were previously extracted (Swisher et al. 2016) and tested by additional methods in this study. All insect nucleic acids were resuspended in $50 \mu \mathrm{l}$ of water for subsequent molecular analyses.

PCR analysis. To ensure that the nucleic acid extractions were successful for the pepper plants tested and to avoid false negatives, all pepper samples were subjected to PCR of the potato $18 \mathrm{~S}$ ribosomal DNA (rDNA) gene with primers pot18s1 and pot18s2 (Munyaneza et al. 2010; Table 1). The reaction consisted of $5 \mu$ l of $5 \times$ GoTaq Green PCR buffer, $0.25 \mu \mathrm{l}$ of $10 \mathrm{mM}$ dNTP (each), $0.5 \mu \mathrm{l}$ of $20 \mu \mathrm{M}$ forward and reverse primers, $17.65 \mu \mathrm{l}$ of $\mathrm{H}_{2} \mathrm{O}, 1 \mu \mathrm{l}$ of nucleic acid extract, and $0.1 \mu \mathrm{l}$ of GoTaq DNA polymerase (Promega Corp.). The thermal cycling program consisted of $94^{\circ} \mathrm{C}$ for $3 \mathrm{~min}$; followed by 39 cycles of $94^{\circ} \mathrm{C}$ for $20 \mathrm{~s}, 65^{\circ} \mathrm{C}$ for $20 \mathrm{~s}$, and $72^{\circ} \mathrm{C}$ for $1 \mathrm{~min}$; and a final extension step of $72^{\circ} \mathrm{C}$ for $5 \mathrm{~min}$. All PCR products were visualized on a $1.5 \%$ agarose gel after ethidium bromide staining. The expected product size was $529 \mathrm{bp}$.

Polymerase chain reaction was used to detect the ' $\mathrm{Ca}$. L. solanacearum,' phytoplasma, curtovirus, and S. citri pathogens in the plant and insect nucleic acid extracts. All reactions were conducted as above for the 18S rDNA gene. All PCR included a positive nucleic acid control from a sample previously identified as positive for the specific pathogen, and a negative water control. For detection of ' $\mathrm{Ca}$. L. solanacearum', primers OA2 and OI2c (Table 1) were used with the thermal cycling program listed by Crosslin et al. (2011). For universal detection of phytoplasmas, a nested PCR analysis was used with primers P1 and P7 followed by FU5 and RU3 (Table 1) (Crosslin et al. 2006). For the second round of PCR (nested reaction), $1 \mu$ l of nucleic acid extract was replaced with $1 \mu l$ of a 1:20 dilution of the first-round PCR. The thermal cycling program was previously described by Crosslin et al.

Table 1. List of primers used in this study

\begin{tabular}{|c|c|c|c|}
\hline Target & Name & Sequence $\left(5^{\prime}-3^{\prime}\right)$ & Reference \\
\hline Potato $18 \mathrm{~S}$ rDNA gene & Pot18S1 & TCGCTCCACCAACTAAGAAC & Munyaneza et al. 2010 \\
\hline Potato $18 \mathrm{~S}$ rDNA gene & Pot18S2 & AGCAAGCCTACGCTCTGTAT & Munyaneza et al. 2010 \\
\hline 'Candidatus Liberibacter solanacearum' $16 \mathrm{~S}$ & OA2 & GCGCTTATTTTTAATAGGAGCGGCA & Liefting et al. 2009 \\
\hline 'Ca. L. solanacearum' $16 \mathrm{~S}-23 \mathrm{~S}$ & $\mathrm{OI} 2 \mathrm{c}$ & GCCTCGCGACTTCGCAACCCAT & Jagoueix et al. 1996 \\
\hline Universal phytoplasma & $\mathrm{P} 1$ & AAGAGTTTGATCCTGGCTCAGGATT & Deng and Hiruki 1991 \\
\hline Universal phytoplasma & P7 & CGTCCTTCATCGGCTCTT & Schneider et al. 1995 \\
\hline Universal phytoplasma & FU5 & CGGCAATGGAGGAAACT & Lorenz et al. 1995 \\
\hline Universal phytoplasma & RU3 & TTCAGCTACTCTTTGTAACA & Lorenz et al. 1995 \\
\hline $\begin{array}{l}\text { Beet leafhopper transmitted virescence agent } \\
\text { phytoplasma }\end{array}$ & BLTVA-int & GATGATTTTAGTATATATAGTCC & Smart et al. 1996 \\
\hline Universal phytoplasma & R16F2n & GAAACGACTGCTAAGACTGG & Gundersen and Lee 1996 \\
\hline Universal phytoplasma & R16R2 & TGACGGGCGGTGTGTACAAACCCCG & Gundersen and Lee 1996 \\
\hline Universal curtovirus coat protein & BCTV2-F & GTGGATCAATTTCCAGACAATTATC & Strausbaugh et al. 2008 \\
\hline Universal curtovirus coat protein & BCTV2-R & CCCATAAGAGCCATATCAAACTTC & Strausbaugh et al. 2008 \\
\hline B. cockerelli $\mathrm{CO} 1$ & $\mathrm{CO} 1 \mathrm{~F} 3$ & TACGCCATACTAGCAATCGG & Crosslin et al. 2011 \\
\hline B. cockerelli $\mathrm{CO} 1$ & $\mathrm{CO} 1 \mathrm{meltF}$ & GGATTCATTGTTTGAGCACATC & Chapman et al. 2010 \\
\hline B. cockerelli $\mathrm{CO} 1$ & CO1 meltR & TGAAATAGGCACGAGAATCAA & Chapman et al. 2010 \\
\hline B. cockerelli $\mathrm{CO} 1$ & CO1 R3 & GAGTAACGTCGTGGTATTCC & Crosslin et al. 2011 \\
\hline 'Ca. L. solanacearum' haplotyping & SSR-1F & TTATTTTGAGATGGTTTGTTAAATG & Lin et al. 2012 \\
\hline 'Ca. L. solanacearum' haplotyping & SSR-1R & TATTATCATTCTATTGCCTATTTCG & Lin et al. 2012 \\
\hline
\end{tabular}


(2006). These same conditions were used for PCR analysis with the universal phytoplasma primer pair P1/P7 followed by primer pair $\mathrm{R} 16 \mathrm{~F} 2 \mathrm{n} / \mathrm{R} 16 \mathrm{R} 2$ (Table 1), which amplify a region specific for restriction fragment length polymorphism (RFLP) analysis. To detect the specific BLTVA phytoplasma, a nested PCR with primer pair P1/P7 followed by FU5/BLTVA-int (Table 1) was used with the same conditions listed for the universal phytoplasma detection. Curtovirus detection was done using primers BCTV2-F and BCTV2-R (Table 1), which amplify a region of the viral coat protein of all curtoviruses (Strausbaugh et al. 2008). Thermal cycling conditions were previously described by Strausbaugh et al. (2008). Conditions for PCR analysis of S. citri were described by Swisher et al. (2016). All PCR products for ' $C a$. L. solanacearum', phytoplasma, and curtovirus were visualized on $1.5 \%$ agarose gels after ethidium bromide staining. Expected PCR product sizes for ' $\mathrm{Ca}$. L. solanacearum', universal phytoplasma FU5/RU3, universal phytoplasma R16F2n/R16R2, BLTVA phytoplasma, and universal curtovirus were 1,168, 879, 1,250, 1,192, and 516 bp, respectively (Crosslin et al. 2006, 2011; Strausbaugh et al. 2008).

'Ca. L. solanacearum' haplotype and B. cockerelli psyllid haplotype were also subject to PCR analysis using the same PCR setup listed above for pathogen detection. ' $\mathrm{Ca}$. L. solanacearum' haplotyping analyses were conducted using primers ' $C a$. L. solanacearum' SSR-1F and ' $C a$. L. solanacearum' SSR-1R (Table 1), with a thermal cycling program previously described by Wen et al. (2013). Products were visualized on a $2 \%$ agarose gel after ethidium bromide staining. Haplotypes were distinguished by bands of different sizes, with a 240-bp PCR product for ' $\mathrm{Ca}$. L. solanacearum' A and a 180-bp PCR product for ' $\mathrm{Ca}$. L. solanacearum' B (Wen et al. 2013). To verify B. cockerelli haplotypes, sequencing analysis of a 500-bp region of the mitochondrial cytochrome oxidase I (CO1) gene was done using primers CO1 F3 and CO1 R3 (Table 1), with thermal cycling conditions described by Crosslin et al. (2011). Products were visualized on a $1.5 \%$ agarose gel after ethidium bromide staining.

Cloning and sequencing analysis. Sequencing confirmation was used to verify the PCR results for pathogen detection and B. cockerelli haplotyping analyses by either direct sequencing analysis or by sequencing clones. All PCR were purified using the GeneJET PCR purification kit (Fisher Scientific) prior to either sequence analysis or cloning. For cloning reactions, all purified PCR amplicons were cloned into Top-10 cells using the TOPO TA cloning kit with the pCR2.1-TOPO vector (Invitrogen). Cells were plated on imMedia Growth Medium agar (Life Technologies) and isolated using the GeneJET plasmid miniprep kit (Fisher Scientific). Three clones from each sample were submitted for sequencing analysis, and a consensus sequence was generated from these clones.

For validation of ' $\mathrm{Ca}$. L. solanacearum' infection and the specific ' $\mathrm{Ca}$. L. solanacearum' haplotype present, the 1,168-bp amplicon generated with primer pair $\mathrm{OA} 2 / \mathrm{OI} 2 \mathrm{c}$ was subject to both direct sequencing analysis and sequencing of clones for 15 pepper samples ( 3 by direct sequencing and 9 by cloning) and 10 psyllid samples ( 7 by direct sequencing and 3 by cloning). All consensus sequences generated from cloning and all direct sequences were then subject to BLAST analysis. ' $\mathrm{Ca}$. L. solanacearum' haplotype was identified using two single-nucleotide polymorphisms located in the $16 \mathrm{~S}$ region, $212 \mathrm{~T}>\mathrm{G}$ and $581 \mathrm{~T}>\mathrm{C}$, as published previously (Nelson et al. 2013)

Verification and identification of the specific curtovirus strains present in pepper and leafhopper samples was done by cloning and sequencing the 496-bp amplicon of the curtovirus coat protein generated from primers BCTV2-F and BCTV2-R. In all, 12 pepper samples and 3 leafhopper samples were analyzed by sequencing analysis for curtovirus infection. A consensus sequence was generated for 11 of the 12 pepper samples; the 12th sample was infected with two strains of curtovirus and, therefore, a single consensus sequence could not be generated. All sequences were subjected to BLAST analysis.

For validation of phytoplasma infection in the potato psyllids, the 1,192-bp FU5/BLTVA-int amplicon was cloned and sequenced from eight different psyllid samples. An 879-bp FU5/RU3 universal phytoplasma amplicon was also cloned and sequenced from an additional sample that was negative for BLTVA. A consensus sequence was generated for each sample, and these sequences were subject to BLAST analysis. Additionally, the approximately 1,250-bp amplicon generated with primers R16F2n and R16R2 was also cloned and sequenced from seven different psyllid samples that were BLTVA infected and the single psyllid sample that was infected with phytoplasma other than BLTVA. Two consensus sequences were generated from all clones; one was generated from the BLTVA-infected samples and the other was generated from the sample infected with a phytoplasma other than BLTVA. Both consensus sequences were subjected to in silico RFLP analysis using the iPhyClassifier online tool (Zhao et al. 2009).

The $C O 1$ region of $16 \mathrm{~B}$. cockerelli samples was direct sequenced using the $\mathrm{CO} 1 \mathrm{~F} 3$ and $\mathrm{CO} 1 \mathrm{R} 3$ primers, generating sequences of 479 to $500 \mathrm{bp}$ in length. These sequences were then compared with sequences of the known central (GenBank Accession number JQ708094), western (JQ708095), northwestern (JQ708093), and southwestern (KC305359) haplotypes, and their respective haplotypes were identified.

B. cockerelli haplotyping analysis. High-resolution melting (HRM) analysis was used to identify the psyllid haplotypes present in a subset of the psyllid samples. Two different primer pairs were used to identify the haplotype, including $\mathrm{CO} 1$ meltF/CO1 meltR and CO1 F3/CO1 meltR, using the LightCycler 480 machine and the LightCycler 480 gene scanning software, as outline previously (Table 1) (Swisher et al. 2013). Controls of known central, western, northwestern, and southwestern haplotypes were used to identify the haplotype of the unknown samples.

\section{Results}

Analysis of Capsicum annuum samples. Symptomatic Capsicum annuum tissue was analyzed by PCR for the presence of ' $\mathrm{Ca}$. L. solanacearum', phytoplasma, and curtoviruses (Table 2). PCR analysis detected ' $\mathrm{Ca}$. L. solanacearum' and curtovirus infection in pepper collected from all nine locations. BLTVA phytoplasma infection was only detected in pepper collected from seven of the nine locations. Yurécuaro, Michoacán, and Jalpa, Zacatecas, the two southern-most locations where samples were collected in this study, did not have BLTVA-infected plants. Throughout all locations sampled, with the exception of Poanas, Durango, coinfections of the bacterial or viral pathogens were very common. The highest percentage of infection across all locations and all samples was coinfection of BLTVA phytoplasma and curtovirus $(30.5 \%)$. In the central and northeastern regions of Zacatecas, triple infection with ' $\mathrm{Ca}$. L. solanacearum', BLTVA, and a curtovirus ranged from 2.8 to $14.6 \%$ across the five different locations sampled (Table 2). Infection at each location sampled ranged from 27.3 to $100 \%$. Overall, ' $C a$. L. solanacearum', BLTVA, and curtoviruses were found in $23.3,47.3$, and $50.1 \%$ of the pepper sampled, respectively.

Analysis of Circulifer tenellus samples. In total, 52 beet leafhoppers (Circulifer tenellus) were collected in September and October 2014 in the state of Zacatecas, Mexico from pepper fields and weeds surrounding the fields. All samples were tested for curtoviruses, as well as BLTVA phytoplasma (Swisher et al. 2017) and S. citri, another bacterial pathogen transmitted by the leafhopper (Swisher et al. 2016) (Table 3). Coinfection of the bacterial and viral pathogens was common, including $7.7 \%$ with a triple infection of BLTVA, S. citri, and curtovirus. Infection of the beet leafhoppers ranged from 72.7 to $80 \%$ at each location where samples were collected and analyzed. Overall, BLTVA was found in $46.2 \%$, S. citri was found in $36.5 \%$, and curtoviruses were found in $40.4 \%$ of the beet leafhoppers analyzed.

Analysis of $\boldsymbol{B}$. cockerelli samples. Potato psyllids (B. cockerelli) were collected between late September and early November 2014, in pepper fields, tomato fields, or weeds located nearby pepper fields in the states of Durango, Zacatecas, and Michoacán, Mexico and tested by PCR for the presence of ' $\mathrm{Ca}$. L. solanacearum' and phytoplasma (Table 4). 'Ca. L. solanacearum' infection was found in samples from each collection location and was the most prevalent bacteria identified in the psyllids, at an infection rate of $35.0 \%$. BLTVA phytoplasma infection was in $8.7 \%$ of the psyllids analyzed, and infection with a phytoplasma other than BLTVA was in $0.4 \%$ (one sample). Phytoplasma infection was not found in psyllids tested from Yurécuaro, Michoacán, and Jalpa, Zacatecas (the two southern-most collection sites) or from Sombrerete, Zacatecas. Coinfection between ' $\mathrm{Ca}$. L. solanacearum' 
and phytoplasma was detected in $3.8 \%$ of the total samples. Overall, infection of the potato psyllids ranged from 4.5 to $100 \%$ at each location where samples were collected and analyzed.

A subset of B. cockerelli samples from each sampling date and collection site in Mexico was analyzed for psyllid haplotype using HRM analysis that targeted a region of the $\mathrm{COl}$ gene in the psyllid mitochondrial DNA. Of 115 psyllids analyzed, $113(98.3 \%)$ belonged to the central psyllid haplotype (Table 4$)$. The remaining two psyllids (1.7\%) belonged to the western psyllid haplotype. One western psyllid was collected from El Saladillo, Zacatecas on 24 October 2014 and the other from Jalpa, Zacatecas on 4 November 2014. Haplotypes identified by HRM were confirmed by DNA sequencing analysis for 16 psyllid samples.
Analysis of ' $\mathrm{Ca}$. L. solanacearum' haplotype in Capsicum annuum and B. cockerelli samples. Pepper and psyllid samples identified as ' $\mathrm{Ca}$. L. solanacearum' positive by conventional PCR were further tested for ' $\mathrm{Ca}$. L. solanacearum' haplotype. The ' $\mathrm{Ca}$. L. solanacearum' haplotype of 78 of 90 ' $\mathrm{Ca}$. L. solanacearum'-infected pepper and 88 of 99 ' $\mathrm{Ca}$. L. solanacearum'-infected psyllids was identified by conventional PCR targeting a simple-sequence repeat region (Table 5). Among the pepper and psyllid samples, both ' $\mathrm{Ca}$. L. solanacearum' haplotypes $\mathrm{A}$ and $\mathrm{B}$ were found at each sampling location in the states of Durango, Zacatecas, and Michoacán. Confirmation of these results was done by DNA sequence analysis of an 1,168-bp region of the $16 \mathrm{~S}$ rRNA gene in 15 different pepper samples ( 9 by cloning and 6 by direct sequencing)

Table 2. Number of pepper samples from the Mexican states of Durango, Zacatecas, and Michoacán in 2014 with leafhopper- and psyllid-related pathogens

\begin{tabular}{|c|c|c|c|c|c|c|c|c|c|c|}
\hline \multirow[b]{2}{*}{ Collection location } & \multirow[b]{2}{*}{ Date $^{\mathbf{b}}$} & \multirow[b]{2}{*}{ Type } & \multicolumn{8}{|c|}{ Number of samples $(\%)^{\mathrm{a}}$} \\
\hline & & & Ca. & BLTVA & Curt & $\begin{array}{c}\text { Ca. }+ \\
\text { BLTVA }\end{array}$ & Ca. + Curt & $\begin{array}{c}\text { BLTVA + } \\
\text { Curt }\end{array}$ & Ca. $+\underset{\text { Curt }}{\text { BLTVA }}+$ & Tested \\
\hline Poanas, Durango & $29 \mathrm{Sep}$ & Chili & $5(15.2)$ & $3(9.1)$ & $1(3.0)$ & $\ldots$ & $\ldots$ & $\ldots$ & $\ldots$ & 33 \\
\hline Sombrerete, Zacatecas & 29 Sep & Chili & $\ldots$ & $4(57.1)$ & $\ldots$ & $2(28.6)$ & $\ldots$ & $1(14.3)$ & $\ldots$ & 7 \\
\hline Calera de V.R., Zacatecas & $18 \mathrm{Sep}$ & Chili & $\ldots$ & $2(4.9)$ & $1(2.4)$ & $1(2.4)$ & $1(2.4)$ & $28(68.3)$ & $6(14.6)$ & 41 \\
\hline Villa de Cos, Zacatecas & 6 Oct & Chili & $\ldots$ & $3(9.1)$ & $6(18.2)$ & $\ldots$ & $\ldots$ & $20(60.6)$ & $4(12.1)$ & 33 \\
\hline Laguna Seca, Zacatecas & 6 Oct & Chili & $\ldots$ & $5(12.5)$ & $8(20.0)$ & $\ldots$ & $1(2.5)$ & $21(52.5)$ & $5(12.5)$ & 40 \\
\hline La Blanca, Zacatecas & 20 Oct & Chili & $\ldots$ & $7(9.9)$ & $13(18.3)$ & $\ldots$ & $2(2.8)$ & $45(63.4)$ & $2(2.8)$ & 71 \\
\hline Chupaderos, Zacatecas & 20 Oct & Bell \& Chili & $2(5.7)$ & 17 (48.6) & $3(8.6)$ & $3(8.6)$ & $1(2.9)$ & $3(8.6)$ & $1(2.9)$ & 35 \\
\hline Yurécuaro, Michoacán & 28 Oct & Bell & $14(21.5)$ & $\ldots$ & $12(18.5)$ & $\ldots$ & $2(3.1)$ & $\ldots$ & $\ldots$ & 65 \\
\hline Jalpa, Zacatecas & $4 \mathrm{Nov}$ & Chili & $33(53.2)$ & $\ldots$ & $2(3.2)$ & $\ldots$ & $5(8.1)$ & $\ldots$ & $\ldots$ & 62 \\
\hline Totals & $\ldots$ & $\ldots$ & $54(14.0)$ & 41 (10.6) & $46(11.9)$ & $6(1.6)$ & $12(3.1)$ & $118(30.5)$ & $18(4.7)$ & 387 \\
\hline
\end{tabular}

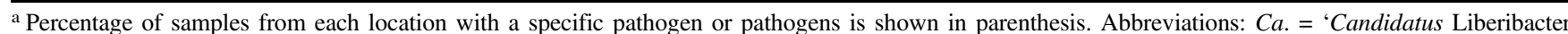
solanacearum', BLTVA = beet leafhopper-transmitted virescence agent, Curt $=$ curtovirus, and Tested $=$ total number samples tested.

${ }^{\mathrm{b}}$ Date of collection in September (Sep), October (Oct), and November (Nov) 2014.

Table 3. Number of leafhoppers from Zacatecas, Mexico in 2014 infected with phloem-limited pathogens

\begin{tabular}{|c|c|c|c|c|c|c|c|c|c|c|}
\hline \multirow[b]{2}{*}{ Collection location } & \multirow[b]{2}{*}{ Date $^{\mathbf{b}}$} & \multirow[b]{2}{*}{ Host plants } & \multicolumn{8}{|c|}{ Number of samples $(\%)^{\mathbf{a}}$} \\
\hline & & & BLTVA & Spiro & Curt & BLTVA + Spiro & $\begin{array}{c}\text { BLTVA + } \\
\text { Curt }\end{array}$ & Curt + Spiro & $\begin{array}{c}\text { BLTVA + } \\
\text { Spiro + Curt }\end{array}$ & Tested \\
\hline Calera de V.R. & $18 \mathrm{Sep}$ & Pepper \& weeds & 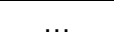 & $\ldots$ & $8(72.7)$ & $\ldots$ & $\ldots$ & $\ldots$ & $\ldots$ & 11 \\
\hline Villa de Cos & 6 Oct & Pepper \& weeds & $2(9.1)$ & $4(18.2)$ & $1(4.5)$ & $4(18.2)$ & $4(18.2)$ & $\ldots$ & $2(9.1)$ & 22 \\
\hline El Saladillo & 20 Oct & Weeds & $2(20)$ & $\ldots$ & $2(20)$ & $2(20)$ & $1(10)$ & $\ldots$ & $1(10)$ & 10 \\
\hline El Saladillo & 28 Oct & Weeds & $1(11.1)$ & $\ldots$ & $\ldots$ & $4(44.4)$ & $\ldots$ & $1(11.1)$ & $1(11.1)$ & 9 \\
\hline Totals & $\ldots$ & $\ldots$ & $5(9.6)$ & $4(7.7)$ & $11(21.2)$ & $10(19.2)$ & $5(9.6)$ & $1(1.9)$ & $4(7.7)$ & 52 \\
\hline
\end{tabular}

a Percentage of leafhopper samples from each location that are infected with a specific pathogen or pathogens is shown in parenthesis. Abbreviations: BLTVA $=$ beet leafhopper-transmitted virescence agent, Spiro $=$ spiroplasma, Curt $=$ curtovirus, and Tested $=$ total number samples tested.

${ }^{\mathrm{b}}$ Date of collection in September (Sep) and October (Oct) 2014.

Table 4. Number of psyllids collected from the Mexican states of Durango, Zacatecas, and Michoacán, in 2014 infected with phloem-limited pathogens

\begin{tabular}{|c|c|c|c|c|c|c|c|c|}
\hline \multirow[b]{2}{*}{ Collection location } & \multirow[b]{2}{*}{ Date $^{\mathbf{b}}$} & \multirow[b]{2}{*}{ Host plants } & \multicolumn{6}{|c|}{ Number of samples $(\%)^{\mathrm{a}}$} \\
\hline & & & Ca. & BLTVA & $\begin{array}{c}C a .+ \text { PHY } \\
\text { (other) }\end{array}$ & Ca. + BLTVA & Tested & Psyllid haplotype \\
\hline Poanas, Durango & $29 \mathrm{Sep}$ & Pepper & $6(85.7)$ & $1(14.3)$ & $\ldots$ & $\ldots$ & 7 & 7 Central \\
\hline Sombrerete, Zacatecas & 29 Sep & Pepper & $6(33.3)$ & & $\ldots$ & $\ldots$ & 18 & 10 Central \\
\hline Calera de V.R., Zacatecas & 18 Sep & Pepper \& weeds & $17(32.7)$ & $2(3.8)$ & $\ldots$ & $6(11.5)$ & 52 & 20 Central \\
\hline Villa de Cos, Zacatecas & 6 Oct & Pepper & $15(11.5)$ & $9(22.5)$ & $\ldots$ & $2(5.0)$ & 40 & 10 Central \\
\hline El Saladillo, Zacatecas & 20 Oct & Pepper & $1(12.5)$ & $2(25.0)$ & $\ldots$ & $1(12.5)$ & 8 & 5 Central \\
\hline Guadalupe, Zacatecas & $20 \mathrm{Oct}$ & Pepper & $10(35.7)$ & $1(3.6)$ & $1(3.6)$ & $1(3.6)$ & 28 & 15 Central \\
\hline Chupaderos, Zacatecas & $24 \mathrm{Oct}$ & Pepper & $1(12.5)$ & $\ldots$ & $\ldots$ & $\ldots$ & 8 & 8 Central \\
\hline El Saladillo, Zacatecas & 24 Oct & Pepper & $1(4.5)$ & $\ldots$ & $\ldots$ & $\ldots$ & 22 & 9 Central, 1 Western \\
\hline Yurécuaro, Michoacán & 28 Oct & Tomato \& pepper & $16(19.8)$ & $\ldots$ & $\ldots$ & $\ldots$ & 81 & 20 Central \\
\hline Jalpa, Zacatecas & $4 \mathrm{Nov}$ & Pepper & $16(72.7)$ & $\ldots$ & $\ldots$ & $\ldots$ & 22 & 9 Central, 1 Western \\
\hline Totals & $\ldots$ & $\ldots$ & $89(31.1)$ & $15(5.2)$ & $1(0.4)$ & $10(3.5)$ & 286 & $98.3 \%$ Central, $1.7 \%$ Western \\
\hline
\end{tabular}

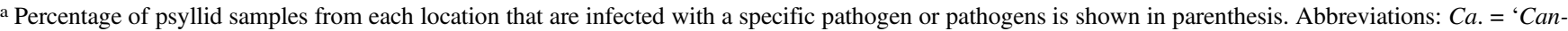
didatus Liberibacter solanacearum', BLTVA = beet leafhopper-transmitted virescence agent, and Tested = total number samples tested.

${ }^{\mathrm{b}}$ Date of collection in September (Sep), October (Oct), and November (Nov) 2014. 
and 10 different psyllid samples ( 3 by cloning and 7 by direct sequencing).

Two consensus sequences were generated from nine pepper samples cloned and sequenced (three clones each). One consensus sequence was generated from seven samples analyzed from Poanas, Durango (2 samples); Sombrerete, Zacatecas (1 sample); Laguna Seca, Zacatecas (1 sample); Yurécuaro, Michoacán (2 samples); and Jalpa, Zacatecas (1 sample). This consensus sequence was $100 \%$ identical to GenBank reference sequence EU812559.1, designated as ' $\mathrm{Ca}$. L. solanacearum' haplotype A (Nelson et al. 2011). The second consensus sequence was generated from two pepper samples analyzed from Villa de Cos, Zacatecas and Jalpa, Zacatecas. This consensus sequence was 100\% identical to GenBank reference sequence FJ829807.1, designated as ' $\mathrm{Ca}$. L. solanacearum' haplotype B (Nelson et al. 2011). Direct sequence analysis of the 16S rRNA gene generated sequences of 877 to $989 \mathrm{bp}$ from six pepper samples. Single samples from Laguna Seca and Calera de V.R., Zacatecas were 100\% identical to GenBank accession EU812559.1 for ' $C a$. L. solanacearum' haplotype A. Three samples, one from Calera de V.R. and two from La Blanca, Zacatecas were only $99 \%$ identical to 'Ca. L. solanacearum' haplotype A (EU812559.1); the difference likely was a result of errors generated from direct sequencing. A single sample from Chupaderos, Zacatecas was $100 \%$ identical to GenBank accession FJ829807.1 for ' $\mathrm{Ca}$. L. solanacearum' haplotype B.

Two consensus sequences were also generated from three psyllid samples cloned and sequenced (three clones each). One consensus sequence generated from one sample from El Saladillo, Zacatecas and one from Yurécuaro, Michoacán was $100 \%$ identical to GenBank accession EU812559.1, indicating that the samples were ' $\mathrm{Ca}$. L. solanacearum' haplotype $\mathrm{A}$. The second consensus sequence was generated from a sample from Poanas, Durango and was $100 \%$ identical to GenBank accession FJ829807.1, indicating that the sample was ' $\mathrm{Ca}$. L. solanacearum' haplotype B. The 16S rRNA gene from seven additional psyllid samples were determined by direct sequencing analysis, which resulted in amplicons of 941 to 1,004 bp. One sample from Poanas, Durango was 99\% identical to GenBank accession EU812559.1 for ' $\mathrm{Ca}$. L. solanacearum' haplotype A. One sample from Jalpa, Zacatecas was $100 \%$ identical to GenBank accession FJ829807.1 for ' $\mathrm{Ca}$. L. solanacearum' haplotype
B. Five additional samples from Sombrerete (2 samples), Calera de V.R. (1 sample), Guadalupe (1 sample), and Villa de Cos (1 sample), Zacatecas were all 99\% similar to FJ829807.1; the differences likely were due to direct sequencing errors.

Analysis of Curtovirus spp. and strains present in Capsicum annuum and Circulifer tenellus. Cloning and DNA sequence analysis of an approximately 516-bp amplicon of the curtovirus viral coat protein was used to identify the species and strains present in 12 pepper samples from the states of Durango, Zacatecas, and Michoacán that were positive by PCR with universal curtovirus primers (Table 6). Two-thirds $(n=8)$ of the samples analyzed were infected with BCTV-Mld, previously identified as a Beet mild curly top virus species. One sample from Villa de Cos, Zacatecas (GenBank MF092772) shared $99 \%$ identity in this viral coat protein region with a Curtovirus sp. designated as BCTV-Mld (MX-Mld-06) (GenBank EU193175) (Varsani et al. 2013). A second sample from Villa de Cos, Zacatecas (GenBank MF092773) and one from Laguna Seca, Zacatecas (GenBank MF092774) shared 99\% identity with a Curtovirus sp. designated as BCTV-Mld (MX-Mld-8-10-10) (GenBank accession HQ634913) (Varsani et al. 2013; Velásquez-Valle et al. 2012). Similarly, one sample from Calera de V.R., Zacatecas (GenBank MF092775), two samples from La Blanca, Zacatecas (GenBank MF092776 and MF092777), one sample from Chupaderos, Zacatecas (GenBank MF092778), and one sample from Yurécuaro, Michoacán (one of three clones, GenBank MF092779) shared between 98 and 99\% identity with GenBank accession HQ214016, a Curtovirus sp. designated as BCTV-Mld (MX-MldMX-P24-07) (Chen et al. 2011; Varsani et al. 2013).

A second sample from Calera de V.R., Zacatecas (GenBank MF092780) shared 99\% identity with a Curtovirus sp. designated as strain BCTV-SpCT (US-Sp3-96) (GenBank AY548948) (Baliji et al. 2004; Varsani et al. 2013). The species was previously identified as Spinach curly top virus. The curtovirus sequences from a sample from Poanas, Durango (GenBank MF092781) and one from Sombrerete, Zacatecas (MF092782) shared 91\% identity with GenBank accession JX487184, a Curtovirus sp. designated as strain BCTV-PeCT (USCa-BV3-Pep-09) (Varsani et al. 2013). This species was previously identified as Pepper curly top virus.

Table 5. Distribution of 'Candidatus Liberibacter solanacearum' haplotypes in pepper and psyllid samples collected in central Mexico ${ }^{\mathrm{a}}$

\begin{tabular}{|c|c|c|c|c|}
\hline \multirow{2}{*}{$\frac{\text { Collection location }}{\text { Poanas, Durango }}$} & \multicolumn{2}{|c|}{ Pepper } & \multicolumn{2}{|c|}{ Psyllids } \\
\hline & $\mathrm{A}$ & $3 / 5 \mathrm{~A}$ & $\mathrm{~A}, \mathrm{~B}$, and $\mathrm{A} / \mathrm{B}$ & $1 / 7 \mathrm{~A}$ \\
\hline & $\ldots$ & $\ldots$ & $\ldots$ & $3 / 7 \mathrm{~B}$ \\
\hline & $\ldots$ & $\ldots$ & $\ldots$ & $2 / 7 \mathrm{~A} / \mathrm{B}$ \\
\hline Sombrerete, Zacatecas & A & $1 / 2 \mathrm{~A}$ & B & $6 / 18 \mathrm{~B}$ \\
\hline \multirow[t]{2}{*}{ Calera de V.R., Zacatecas } & A & $7 / 8 \mathrm{~A}$ & $\mathrm{~B}$ and $\mathrm{A} / \mathrm{B}$ & $15 / 52 \mathrm{~B}$ \\
\hline & $\ldots$ & $\ldots$ & $\ldots$ & $5 / 52 \mathrm{~A} / \mathrm{B}$ \\
\hline \multirow[t]{3}{*}{ Villa de Cos, Zacatecas } & $\mathrm{B}$ and $\mathrm{A} / \mathrm{B}$ & $3 / 4 \mathrm{~B}$ & $\mathrm{~A}, \mathrm{~B}$, and $\mathrm{A} / \mathrm{B}$ & $1 / 40 \mathrm{~A}$ \\
\hline & $\ldots$ & $1 / 4 \mathrm{~A} / \mathrm{B}$ & $\ldots$ & $14 / 40 \mathrm{~B}$ \\
\hline & $\ldots$ & $\ldots$ & $\ldots$ & $1 / 40 \mathrm{~A} / \mathrm{B}$ \\
\hline \multirow[t]{3}{*}{ Laguna Seca, Zacatecas } & $\mathrm{A}, \mathrm{B}$, and $\mathrm{A} / \mathrm{B}$ & $2 / 6 \mathrm{~A}$ & $\ldots$ & $\ldots$ \\
\hline & $\ldots$ & $2 / 6 \mathrm{~B}$ & $\ldots$ & $\ldots$ \\
\hline & $\ldots$ & $1 / 6 \mathrm{~A} / \mathrm{B}$ & $\ldots$ & $\ldots$ \\
\hline \multirow{2}{*}{ La Blanca, Zacatecas } & $\mathrm{A}$ and $\mathrm{B}$ & $2 / 4 \mathrm{~A}$ & $\ldots$ & $\ldots$ \\
\hline & $\ldots$ & $2 / 4 \mathrm{~B}$ & $\ldots$ & $\ldots$ \\
\hline \multirow{2}{*}{ Guadalupe, Zacatecas } & $\ldots$ & $\ldots$ & $A$ and $B$ & $4 / 28 \mathrm{~A}$ \\
\hline & $\ldots$ & $\ldots$ & $\ldots$ & $6 / 28 \mathrm{~B}$ \\
\hline \multirow[t]{2}{*}{ Chupaderos, Zacatecas } & $\mathrm{A}$ and $\mathrm{B}$ & $5 / 7 \mathrm{~A}$ & B & $1 / 8 \mathrm{~B}$ \\
\hline & $\ldots$ & $1 / 7 \mathrm{~B}$ & $\ldots$ & $\ldots$ \\
\hline \multirow[t]{2}{*}{ El Saladillo, Zacatecas } & $\ldots$ & $\ldots$ & $\mathrm{A}$ and $\mathrm{B}$ & $2 / 30 \mathrm{~A}$ \\
\hline & $\ldots$ & $\ldots$ & $\ldots$ & $1 / 30 \mathrm{~B}$ \\
\hline \multirow[t]{2}{*}{ Yurécuaro, Michoacán } & $\mathrm{A}$ and $\mathrm{B}$ & $15 / 16 \mathrm{~A}$ & $A$ and $B$ & $6 / 81 \mathrm{~A}$ \\
\hline & $\ldots$ & $1 / 16 \mathrm{~B}$ & $\ldots$ & 4/81 B \\
\hline \multirow[t]{3}{*}{ Jalpa, Zacatecas } & $\mathrm{A}, \mathrm{B}$, and $\mathrm{A} / \mathrm{B}$ & $12 / 38 \mathrm{~A}$ & $\mathrm{~A}, \mathrm{~B}$, and $\mathrm{A} / \mathrm{B}$ & $1 / 22 \mathrm{~A}$ \\
\hline & $\ldots$ & $18 / 38 \mathrm{~B}$ & $\ldots$ & $13 / 22 \mathrm{~B}$ \\
\hline & $\ldots$ & $2 / 38 \mathrm{~A} / \mathrm{B}$ & $\ldots$ & $2 / 22 \mathrm{~A} / \mathrm{B}$ \\
\hline \multirow[t]{3}{*}{ Totals } & $\ldots$ & $47(60.3 \%) \mathrm{A}$ & $\ldots$ & $15(17.0 \%) \mathrm{A}$ \\
\hline & $\ldots$ & $27(34.6 \%) \mathrm{B}$ & $\ldots$ & $63(71.6 \%) \mathrm{B}$ \\
\hline & $\ldots$ & $4(5.1 \%) \mathrm{A} / \mathrm{B}$ & $\ldots$ & $10(11.4 \%) \mathrm{A} / \mathrm{B}$ \\
\hline
\end{tabular}

\footnotetext{
${ }^{a}$ Data shown are number of samples positive for the specific ' $\mathrm{Ca}$. L. solanacearum'/total number of samples tested from the specific location.
} 
Sequence analysis of the sample from Yurécuaro, Michoacán showed infection with two different curtovirus strains. Two of three clones (GenBank MF092783) shared only 92\% identity with a Curtovirus sp. designated as strain BCTV-SvrPep (US-SVR-NM-Pep-01) (GenBank FJ545686) (Lam et al. 2009; Varsani et al. 2013). This species was previously identified as Beet severe curly top virus. Thus, both BCTV-Mld (98\% identity to HQ214016) and a strain only $92 \%$ identical to BCTVSvrPep were identified in a single sample from Yurécuaro. A sample from Laguna Seca, Zacatecas (GenBank MF092784) also shared 92\% identity with GenBank accession FJ545686.

The approximately 516-bp curtovirus amplicon obtained from three individual beet leafhopper samples was cloned and subjected to DNA sequence analysis. A consensus sequence was generated from three clones from a sample from Calera de V.R., Zacatecas (GenBank MF092785) and shared 98\% identity with a Curtovirus sp. designated as BCTV-Mld (MX-Mld-MX-P24-07) (GenBank accession HQ214016) (Chen et al. 2011; Varsani et al. 2013). This strain was previously identified as Beet mild curly top virus. A sample from Villa de Cos, Zacatecas and one from El Saladillo, Zacatecas generated two consensus sequences (GenBank MF092786 and MF092787, respectively) that both shared only $81 \%$ identity with a Curtovirus sp., designated as BCTV-Svr (US-SVR-Cfh) (Stenger 1994; Varsani et al. 2013). This species was previous identified as Beet severe curly top virus.

Confirmation of phytoplasma strains present in $B$. cockerelli. Twenty-six psyllids (9.1\%) were identified as positive for phytoplasma using the universal phytoplasma PCR primers. Targeting these samples with PCR primers for BLTVA phytoplasma identified 25 of the 26 samples as BLTVA positive (Table 4). To confirm these results and identify the phytoplasma strain present in the 26th sample, 9 samples were subject to PCR with universal phytoplasma primers and BLTVA-specific primers, followed by cloning and sequencing. Sequencing analysis of the 1,192-bp BLTVA-specific amplicon from one sample collected from Poanas, Durango; three samples from Calera de V.R., Zacatecas; one sample from Guadalupe, Zacatecas; and two samples from Villa de Cos, Zacatecas (base pairs 224 to 1,415, GenBank accession MF092788) were $100 \%$ identical to Columbia Basin potato purple top phytoplasma (also known as BLTVA phytoplasma, GenBank accession KR072666.1), a member of the 16 SrVI Clover proliferation group phytoplasma. An additional sample from El Saladillo, Zacatecas contained a single nucleotide polymorphism at nucleotide 1,109 of the 1,192-bp amplicon (base pairs 224 to 1,415, GenBank accession MF092789) and was 99\% identical to Columbia Basin potato purple top phytoplasma (KR072666.1). Amplification with universal phytoplasma primers of a sample from Guadalupe, Zacatecas that was phytoplasma positive but BLTVA negative generated an 879-bp amplicon (base pairs 222 to 1,100, GenBank accession MF092790) that was $100 \%$ identical to several phytoplasma sequences, including 'Cucumis sativus' stunt virescence phytoplasma (GenBank accession KX298483.1), potato witches'-broom phytoplasma (KR338840.1), Aster yellows phytoplasma (KC000006.1), Chrysanthemum yellows phytoplasma (HQ589187.1), and potato purple top phytoplasma (DQ174114.1), most of which are recognized in GenBank as members of the 'Candidatus Phytoplasma asteris' group 16SrI.

An approximately 1,250-bp region from the samples collected from Zacatecas was subsequently targeted for PCR amplification using universal nested phytoplasma primers, followed by cloning and sequencing analysis. All samples, except for the BLTVA-negative sample collected from Guadalupe, were identical in sequence (bp 1-1,250 of GenBank MF092788 and MF092789). The BLTVA-negative sample from Guadalupe, Zacatecas generated a 1,247-bp amplicon (GenBank accession MF092790). Both sequences were then subjected to RFLP analysis using the in silico iPhyClassifier tool (Zhao et al. 2009). The consensus sequence generated from the seven samples shared $99.7 \%$ similarity to ' $\mathrm{Ca}$. P. trifolii' and, based on the RFLP pattern, the sequence was identical to 16SrVI, subgroup A (GenBank accession AY390261). The sequence from the sample from Guadalupe shared $99.4 \%$ similarity to ' $\mathrm{Ca}$. P. asteris' (GenBank accession M30790) and, based on the RFLP pattern, the sequence was identical to 16SrI, subgroup A (GenBank accession NC_007716).

\section{Discussion}

The observation of disease symptoms and high infestation of beet leafhoppers and potato psyllids in and around commercial pepper fields in the central Mexican states of Durango, Zacatecas, and Michoacán prompted the analysis of these pepper samples for leafhopper- and psyllid-transmitted pathogens. This led to the identification of simultaneous infections by both bacterial pathogens (' $\mathrm{Ca}$. L. solanacearum' and BLTVA phytoplasma) and a DNA virus (BCTV strains). To our knowledge, this is the first report of mixed infections in pepper plants with the two bacterial pathogens ' $\mathrm{Ca}$. L. solanacearum' and BLTVA phytoplasma, as well as with these bacterial pathogens and BCTV. Several other studies have identified simultaneous infection in pepper with multiple DNA viruses or multiple RNA viruses (Reveles-Torres et al. 2012; Velásquez-Valle et al. 2014); therefore, it is not surprising that other pathogens are found as mixed infections as well.

Identification of the BCTV species present in pepper and leafhopper samples collected across central Mexico showed wide species diversification. In pepper collected near Poanas, Durango and near Sombrerete, Zacatecas, the BCTV strains were most similar to BCTV-PeCT, previously designated as Pepper curly top virus. In the northeastern region of Zacatecas, near Villa de Cos, Laguna Seca, Calera de V.R., and Chupaderos, various BCTV-Mld strains (previously designated Beet mild curly top virus) were the most common. The BCTV-SvrPep (previously designated Beet severe curly top) and BCTV-SpCT (previously designated Spinach curly top virus) strains were also found in this region in pepper collected from Laguna Seca and Calera de V.R., respectively. Interestingly, the BCTV strains identified in beet leafhopper samples collected in this northeastern region of Zacatecas, near Calera de V.R., Villa de Cos, and El Saladillo, consisted of BCTV-Mld and a BCTV

Table 6. Sequencing and BLAST analysis of curtovirus strains present in pepper and beet leafhopper samples collected in central Mexico in 2014

\begin{tabular}{lclc}
\hline Collection location & GenBank accession number & Sample & Identity to known curtovirus strains (GenBank reference sequence) $^{\mathbf{a}}$ \\
\hline Villa de Cos, Zacatecas & MF092772 & Pepper & $99 \%$ identity to BCTV-Mld (MX-Mld-06) (EU193175) \\
Villa de Cos, Zacatecas & MF092773 & Pepper & $99 \%$ identity to BCTV-Mld (MX-Mld-9-10-10) (HQ634913) \\
Laguna Seca, Zacatecas & MF092774 & Pepper & $99 \%$ identity to BCTV-Mld (MX-Mld-9-10-10) (HQ634913) \\
Calera de V.R., Zacatecas & MF092775 & Pepper & $99 \%$ identity to BCTV-Mld (MX-Mld-MX-P24-07) (HQ214016) \\
La Blanca, Zacatecas & MF092776 & Pepper & $98 \%$ identity to BCTV-Mld (MX-Mld-MX-P24-07) (HQ214016) \\
La Blanca, Zacatecas & MF092777 & Pepper & $99 \%$ identity to BCTV-Mld (MX-Mld-MX-P24-07) (HQ214016) \\
Chupaderos, Zacatecas & MF092778 & Pepper & $98 \%$ identity to BCTV-Mld (MX-Mld-MX-P24-07) (HQ214016) \\
Yurécuaro, Michoacán & MF092779 & Pepper & $98 \%$ identity to BCTV-Mld (MX-Mld-MX-P24-07) (HQ214016) \\
& MF092783 & Pepper & $92 \%$ identity to BCTV-SvrPep (US-SVR-NM-Pep-01) (FJ545686) \\
Calera de V.R., Zacatecas & MF092780 & Pepper & $99 \%$ identity to BCTV-SpCT (US-Sp3-96) (AY548948) \\
Poanas, Durango & MF092781 & Pepper & $91 \%$ identity to BCTV-PeCT (US-Ca-BV3-Pep09) (JX487184) \\
Sombrerete, Zacatecas & MF092782 & Pepper & $91 \%$ identity to BCTV-PeCT (US-Ca-BV3-Pep09) (JX487184) \\
Laguna Seca, Zacatecas & MF092784 & Pepper & $92 \%$ identity to BCTV-SvrPep (US-SVR-NM-Pep-01) (FJ545686) \\
Calera de V.R., Zacatecas & MF092785 & Beet leafhopper & $98 \%$ identity to BCTV-Mild (MX-Mld-MX-P24-07) (HQ214016) \\
Villa de Cos, Zacatecas & MF092786 & Beet leafhopper & $81 \%$ identity to BCTV-Svr (US-SVR-Cfh) (U02311) \\
El Saladillo, Zacatecas & MF092787 & Beet leafhopper & $81 \%$ identity to BCTV-Svr (US-SVR-Cfh) (U02311) \\
\hline
\end{tabular}

${ }^{\mathrm{a}} \mathrm{BCTV}=$ Beet curly top virus. 
isolate distantly related to BCTV-Svr. Near Yurécuaro, Michoacán, a pepper sample showed a mixed infection of BCTV-Mld and BCTVSvrPep. The diversity of the Curtovirus spp. throughout this region of central Mexico is remarkable, and may increase the chances of recombination between the different curtoviruses. Over time, this may cause more problems for growers if the spread of the disease is not controlled.

Analysis of the $B$. cockerelli samples for the presence of phytoplasmas identified a clover proliferation phytoplasma and an aster yellows phytoplasma in the potato psyllid host for the first time, albeit at a low infection rate of less than $10 \%$. This infection rate was much lower than the common leafhopper vector BLTVA phytoplasma prevalence in C. tenellus, which showed a $46 \%$ infection rate from samples collected in the same locations in Mexico. This is the first report of psyllids carrying a phytoplasma of group $16 \mathrm{SrVI}$ subgroup A ( 25 psyllids in this study from the states of Durango and Zacatecas). This study also confirms the previous suggestion that potato psyllids can acquire phytoplasmas of group 16SrI (Garcia-Negroe et al. 2008), and specifies that the psyllid can carry phytoplasma belonging to subgroup A of 16SrI (a single psyllid in this study from Guadalupe, Zacatecas). The presence of phytoplasmas in psyllids is not surprising, because psyllid species that target different host crops have been associated with various phytoplasma species. For example, ' $\mathrm{Ca}$. P. mali' is transmitted by many Cacopsylla vectors and causes the devastating apple proliferation disease. Here, the psyllid plays a significant role in phytoplasma transmission as compared with the less frequently occurring leafhopper Fieberiella florii (Tedeschi and Alma 2006). Although $F$. florii is capable of spreading ' $\mathrm{Ca}$. P. mali,' this scenario highlights the role of insect density in spread of a phytoplasma disease, and may have implications for the potato psyllid and associated phytoplasmas identified in this study. In light of this, further studies are required to determine whether insect density has a role in primary vector transmission of the phytoplasma pathogen and, additionally, to determine whether the psyllid can effectively transmit either phytoplasma strain to pepper or other solanaceous crops.

Additional analysis of the leafhopper and psyllid insect vectors in this study led to the identification of concurrent infection in each insect host. The bacterial pathogens (phytoplasma and $S$. citri) and a DNA virus (BCTV) were found simultaneously in the beet leafhoppers, and the bacterial pathogens (' $\mathrm{Ca}$. L. solanacearum' and phytoplasmas) were found simultaneously in the potato psyllids. Although this information should be of concern to growers trying to prevent the transmission and spread of pathogens among their crop, it is not known whether either of the insect vectors can simultaneously acquire or transmit the pathogens. Given the circulative, persistent manner of transmission of all four of these pathogens, this is an important question that should be studied in the future to better understand the pathogen-host-vector relationships among the bacterial and virus pathogens of pepper and other solanaceous crops.

The presence of high levels of bacterial and viral pathogens in the pepper samples, as well as the simultaneous infection of these plants with multiple pathogens, is alarming not only for growers in this region of Mexico but also for those importing crops of this nature into their countries. For example, in the United States, pepper plants from Mexico are commonly imported, and the presence of phloem-limited pathogens in these plants can have further implications, because both the beet leafhopper and the potato psyllid insect vectors are geographically widespread in the United States and are often present in very high numbers due to their wide range of host crops. High pathogen incidence and the presence of the insect vectors of these pathogens could lead to increased levels of disease in these areas if the insect vectors are not targeted for elimination.

The work described herein highlights the pressing need for pest management in pepper fields in the Mexican states of Durango, Zacatecas, and Michoacán. Although disease symptoms ranged from 5 to $75 \%$ in each field, the identification of multiple pathogen infections in a single sample makes it clear that a high level of disease pressure was present across most fields. The bacterial pathogens (' $\mathrm{Ca}$. L. solanacearum', phytoplasma, and S. citri) and BCTV have the potential to cause more widespread problems in central Mexico (and beyond) if the potato psyllid and the beet leafhopper insect vectors are not controlled.

\section{Acknowledgments}

We thank T. Mustafa, B. Cochran, S. Pettit, and S. Balcom for their technical support in the laboratory. The use of trade, firm, or corporation names in this publication is for the information and convenience of the reader. Such use does not constitute an official endorsement or approval by the USDA or the ARS of any product or service to the exclusion of others that may be suitable. USDA is an equal opportunity provider and employer.

\section{Literature Cited}

Baliji, S., Black, M. C., French, R., Stenger, D. C., and Sunter, G. 2004. Spinach curly top virus: A newly described Curtovirus species from southwest Texas with incongruent gene phylogenies. Phytopathology 94:772-779.

Camacho-Tapia, M., Rojas-Martínez, R. I., Zavaleta-Mejía, E., HernándezDeheza, M. G., Carrillo-Salazar, J. A., Rebollar-Alviter, A., and OchoaMartínez, D. L. 2011. Etiology of chili pepper variegation from Yurécuaro, Mexico. J. Plant Pathol. 93:331-335.

Chapman, R. I., Strube, L., and Bextine, B. 2010. Population genetics of the potato psyllid: Impacts on zebra chip epidemiology. Pages 64-68 in: Proc. 10th Annu. Zebra Chip Rep. Session, Texas AgriLife, College Station, TX.

Chen, L.-F., Vivoda, E., and Gilbertson, R. L. 2011. Genetic diversity in curtoviruses: A highly divergent strain of Beet mild curly top virus associated with an outbreak of curly top disease in pepper in Mexico. Arch. Virol. 156:547-555.

Crosslin, J. M., Lin, H., and Munyaneza, J. E. 2011. Detection of 'Candidatus Liberibacter solanacearum' in potato psyllids, Bactericera cockerelli Sulc, by conventional and real-time PCR. Southwest. Entomol. 36:125-135.

Crosslin, J. M., Vandemark, G. J., and Munyaneza, J. E. 2006. Development of a real-time, quantitative PCR for detection of the Columbia Basin potato purple top phytoplasma in plants and beet leafhoppers. Plant Dis. 90:663-667.

Deng, S., and Hiruki, C. 1991. Amplification of 16S rRNA genes from culturable and nonculturable Mollicutes. J. Microbiol. Methods 14:53-61.

Garcia-Negroe, C. B., Chávez-Medina, J. A., Santos-Cervantes, M. E., Méndez-Lozano, J. M., and Leyva-López, N. E. 2008. Transmission of three groups of phytoplasmas by Bactericera cockerelli to chili plants, potato, and tomato in Sinaloa, Mexico. Page 19 in: Int. Phytoplasmol. Working Group Workshop Abstr. Havana, Cuba.

Greenway, G. 2014. Economic impact of zebra chip control costs on grower returns in seven US states. Am. J. Potato Res. 91:714-719.

Gundersen, D. E., and Lee, I.-M. 1996. Ultrasensitive detection of phytoplasmas by nested-PCR assays using two universal primer pairs. Phytopathol. Mediterr. 35: 144-151.

Jagoueix, S., Bové, J. M., and Garnier, M. 1996. PCR detection of the two 'Candidatus' Liberobacter species associated with greening disease of citrus. Mol. Cell. Probes 10:43-50.

Lam, N., Creamer, R., Rascon, J., and Belfon, R. 2009. Characterization of a new curtovirus, pepper yellow dwarf virus, from chile pepper and distribution in weed hosts in New Mexico. Arch. Virol. 154:429-436.

Liefting, L. W., Sutherland, P. W., Ward, L. I., Paice, K. L., Weir, B. S., and Clover, G. R. G. 2009. A new 'Candidatus Liberibacter' species associated with diseases of solanaceous crops. Plant Dis. 93:208-214

Lin, H., Islam, M. S., Bai, Y., Wen, A., Lan, S., Gudmestad, N. C., and Civerolo, E. L. 2012. Genetic diversity of 'Candidatus Liberibacter solanacearum' strains in the United States and Mexico revealed by simple sequence repeat markers. Eur. J. Plant Pathol. 132:297-308.

Lorenz, K.-H., Schneider, B., Ahrens, U., and Seemüller, E. 1995. Detection of the apple proliferation and pear decline phytoplasmas by PCR amplification of ribosomal and nonribosomal DNA. Phytopathology 85:771-776.

Mauricio-Castillo, J. A., Salas-Muñoz, S., Velásquez-Valle, R., Ambriz-Granados, S., and Reveles-Torres, L. R. 2015. 'Candidatus Phytoplasma trifolli' (16SrVI) in mirasol chili pepper (Capsicum annuum L.) cultivated in Zacatecas, Mexico. Rev. Fitotec. Mex. 38:389-396.

Munyaneza, J. E. 2012. Zebra chip disease of potato: Biology, epidemiology, and management. Am. J. Potato Res. 89:329-350.

Munyaneza, J. E., Crosslin, J. M., and Upton, J. E. 2006. Beet leafhopper (Hemiptera: Cicadellidae) transmits the Columbia basin potato purple top phytoplasma to potatoes, beets, and weeds. J. Econ. Entomol. 99:268-272.

Munyaneza, J. E., Fisher, T. W., Sengoda, V. G., Garczynski, S. F., Nissinen, A., and Lemmetty, A. 2010. Association of "Candidatus Liberibacter solanacearum" with the psyllid, Trioza apicalis (Hemiptera: Triozidae) in Europe. J. Econ. Entomol. 103:1060-1070.

Nelson, W. R., Fisher, T. W., and Munyaneza, J. E. 2011. Haplotypes of "Candidatus Liberibacter solanacearum" suggest long-standing separation. Eur. J. Plant Pathol. 130:5-12.

Nelson, W. R., Sengoda, V. G., Alfaro-Fernandez, A. O., Font, M. I., Crosslin, J. M., and Munyaneza, J. E. 2013. A new haplotype of "Candidatus Liberibacter solanacearum" identified in the Mediterranean region. Eur. J. Plant Pathol. 135: 633-639.

Nielson, M. W. 1968. The leafhopper vectors of phytopathogenic viruses (Homoptera, Cicadellidae): Taxonomy, biology, and virus transmission. No. 1382. U.S Department of Agriculture, Washington, DC.

Reveles-Torres, L. R., Velásquez-Valle, R., Mauricio Castillo, J. A., and SalasMuñoz, S. 2012. Detection of mixed infections caused by Begomovirus and Curtovirus in chili pepper for drying plants in San Luis Potosi, Mexico. Rev. Mex. Fitopatol. 30:155-160. 
Robles-Hernandez, L., Gonzalez-Franco, A. C., Gill-Langarica, E. M., Sago, C., Nikolaeva, O. V., and Karasev, A. V. 2011. First report of Beet severe curly top virus in Jalepeño pepper in Chihuahua, Mexico. Plant Dis. 95:778.

Rojas-Martínez, R. I., Camacho-Tapia, M., Zavaleta-Mejía, E., and Levy, J. 2016. First report of the presence of haplotypes A and B Candidatus Liberibacter solanacearum in chili (Capsicum annuum L.) in the central region of Mexico. J. Plant Pathol. 98:111-115.

Schneider, B., Seemüler, E., Smart, C. D., and Kirkpatrick, B. C. 1995. Phylogenetic classification of plant pathogenic mycoplasma-like organisms or phytoplasma. Pages 369-380 in: Molecular and Diagnostic Procedures in Mycoplasmology, Vol. 1. S. Razin and J. G. Tully, eds. Academic Press, San Diego, CA.

Smart, C. D., Schneider, B., Blomquist, C. L., Guerra, L. J., Harrison, N. A., Ahrens, U., Lorenz, K.-H., Seemüler, E., and Kirkpatrick, B. C. 1996. Phytoplasmaspecific PCR primers based on sequences of the 16S-23S rRNA spacer region. Appl. Environ. Microbiol. 62:2988-2993.

Stenger, D. C. 1994. Complete nucleotide sequence of the hyper-virulent CFH strain of beet curly top virus. Mol. Plant-Microbe Interact. 7:154-157.

Strausbaugh, C. A., Wintermantel, W. M., Gillen, A. M., and Eujayl, I. A. 2008. Curly top survey in the western United States. Phytopathology 98:1212-1217.

Swisher, K. D., Munyaneza, J. E., and Crosslin, J. M. 2013. Temporal and spatial analysis of potato psyllid haplotypes in the United States. Environ. Entomol. 42:381-393.

Swisher, K. D., Munyaneza, J. E., Velásquez-Valle, R., and Mena-Covarrubias, J. 2017. First report of beet leafhopper transmitted virescence agent phytoplasma in Capsicum annuum and Circulifer tenellus in Mexico. Plant Dis. 101:1032.

Swisher, K. D., Velásquez-Valle, R., Mena-Covarrubias, J., and Munyaneza, J. E. 2016. Occurrence and molecular detection of Spiroplasma citri in carrots and its insect vector, Circulifer tenellus, in Mexico. J. Plant Pathol. 98:355-360.
Tedeschi, R., and Alma, A. 2006. Fieberiella florii (Homoptera: Auchenorrhyncha) as a vector of 'Candidatus Phytoplasma mali'. Plant Dis. 90:284-290.

Varsani, A., Martin, D. P., Navas-Castillo, J., Moriones, E., Hernández-Zepeda, C., Idris, A., Zerbini, F. M., and Brown, J. K. 2013. Revisiting the classification of curtoviruses based on genome-wide pairwise identity. Arch. Virol. 159: 1873-1882.

Velásquez-Valle, R., Medina-Aguilar, M. M., and Creamer, R. 2008. First report of Beet mild curly top virus infection of chile pepper in North-Central Mexico. Plant Dis. 92:650.

Velásquez-Valle, R., Reveles-Torres, L. R., and Mena-Covarrubias, J. 2012 Incidence and symptomatology of five viruses in commercial dry chili pepper fields in Aguascalientes, San Luis Potosí, and Zacatecas, Mexico. Rev. Mex. Cienc. Agric. 3:381-390.

Velásquez-Valle, R., Reveles-Torres, L. R., Mena-Covarrubias, J., SalasMuñoz, S., and Mauricio-Castillo, J. A. 2014. Outbreak of Candidatus Liberibacter solanacearum in dried chile pepper in Durango, Mexico. Agrofaz 14:93-98.

Wallis, R. L. 1955. Ecological studies on the potato psyllid as a pest of potatoes, Vol. 1107. U.S. Department of Agriculture, Washington, DC.

Wen, A., Johnson, C., and Gudmestad, N. C. 2013. Development of a PCR assay for the rapid detection and differentiation of 'Candidatus Liberibacter solanacearum' haplotypes and their spatiotemporal distribution in the United States. Am. J. Potato Res. 90:229-236.

Zhao, Y., Wei, W., Lee, I.-M., Shao, J., Suo, X., and Davis, R. E. 2009. Construction of an interactive online phytoplasma classification tool, iPhyClassifier, and its application in analysis of the preach X-disease phytoplasma group 16SrIII. Int J. Syst. Evol. Microbiol. 59:2582-2593. 